\title{
Reduced oxygenation at intermediate depths of the southwest Pacific during the last glacial maximum
}

\author{
Axel Durand ${ }^{\mathrm{a}, *}$, Zanna Chase ${ }^{\mathrm{a}}$, Taryn L. Noble ${ }^{\mathrm{a}}$, Helen Bostock ${ }^{\mathrm{b}}$, Samuel L. Jaccard ${ }^{\mathrm{c}}$, \\ Ashley T. Townsend ${ }^{\mathrm{d}}$, Nathaniel L. Bindoff ${ }^{\mathrm{a}, \mathrm{e}, \mathrm{f}, \mathrm{g}, \mathrm{i}, \text {, Helen Neil }}{ }^{\mathrm{b}}$, Geraldine Jacobsen ${ }^{\mathrm{h}}$ \\ ${ }^{a}$ Institute for Marine and Antarctic Studies, University of Tasmania, Hobart, Australia \\ ${ }^{b}$ National Institute of Water and Atmospheric Research, Wellington, New Zealand \\ ${ }^{c}$ Institute of Geological Sciences and Oeschger Centre for Climate Change Research, University of Bern, \\ Switzerland \\ ${ }^{d}$ Central Science Laboratory, University of Tasmania, Hobart, Australia \\ ${ }^{e}$ Antarctic Climate and Ecosystems Cooperative Research Centre, Hobart, Tasmania, Australia \\ ${ }^{f}$ Commonwealth Scientific and Industrial Research Organisation Marine Atmospheric Research, Hobart, \\ Tasmania, Australia \\ ${ }^{g}$ Collaboration for Australian Weather and Climate Research, Melbourne, Victoria, Australia \\ ${ }^{h}$ Australian Nuclear Science and Technology Organisation, Lucas Heights, New South Wales, Australia \\ ${ }^{i}$ Australian Research Council Centre of Excellence for Climate System Science, Sydney, New South Wales, \\ Australia
}

\section{Abstract}

To investigate changes in oxygenation at intermediate depths in the southwest Pacific between the Last Glacial Maximum (LGM) and the Holocene, redox sensitive elements uranium and rhenium were measured in 12 sediment cores located on the Campbell and Challenger plateaux offshore from New Zealand. The core sites are currently bathed by Subantarctic Mode Water (SAMW), Antarctic Intermediate Water (AAIW) and Upper Circumpolar Deep Water (UCDW). The sedimentary distributions of authigenic uranium and rhenium reveal reduced oxygen content at intermediate depths (800-1500 m) during the LGM compared to the Holocene. In contrast, data from deeper waters ( $\geq$ $1500 \mathrm{~m}$ ) indicate higher oxygen content during the LGM compared to the Holocene. These data, together with variations in benthic foraminiferal $\delta^{13} C$, are consistent with a shallower AAIW-UCDW boundary over the Campbell Plateau during the LGM. Whilst AAIW continued to bathe the intermediate depths $(\leq 1500 \mathrm{~m})$ of the Challenger Plateau during the LGM, the data suggest that the AAIW at these core sites contained less oxygen compared to the Holocene. These results are at odds with the general notion that AAIW

\footnotetext{
*Corresponding author

Email address: axel.durand@utas.edu.au (Axel Durand)
} 
was better oxygenated and expanded deeper during the LGM due to stronger westerlies and colder temperatures. These findings may be explained by an important change in AAIW formation and circulation.

\section{Introduction}

The oxygen content in the ocean interior is determined by the balance between the supply of oxygen by ventilation (the process whereby surface mixed layer water is transported into the ocean interior) on one hand and its removal by bacterial respiration

5 of labile organic matter, associated with remineralisation, on the other. Observations have shown that the oceans have lost $2 \%$ of their total oxygen content since 1960 Schmidtko et al. 2017) and that the rate of deoxygenation has been increasing (Helm et al. 2011). Potential collapse of fisheries and enhancement of global warming in response to this worldwide increasing marine deoxygenation pushed the scientific

10 community to focus on understanding the marine oxygen cycle (Helm et al., 2011, Diaz and Rosenberg, 2008, Keeling et al., 2010; Matear et al., 2000, Bograd et al., 2008; Nevison et al., 1995). Despite this greater attention over the last decade, the complex consequences of climatic forcing on oceanic oxygenation prevent future oxygenation projections from being made accurately (Emerson and Bushinsky, 2014).

This study focuses on the southwest Pacific sector of the Southern Ocean. Today, oceanic productivity in this region is relatively low (Murphy et al., 2001), thus ventilation and 'upstream' oxygen removal related to organic matter remineralisation constitute the primary factors controlling dissolved oxygen levels. Ventilation in this region occurs mainly through the formation of Subantarctic Mode Waters (SAMW)

${ }_{20}$ and Antarctic Intermediate Waters (AAIW), two oxygen rich water masses present at intermediate depths in the Southern Ocean (600-1200 m and 500-600 m, respectively; Figure 1, 2). They are formed by subduction of Antarctic surface waters below buoyant subtropical waters (Talley, 2013). Prior to their subduction, their pre-formation is controlled by the Ekman driven upwelling of oxygen-depleted Upper Circumpolar Deep ${ }_{25}$ Water (UCDW, 1500-2500 m) and Lower Circumpolar Deep Water (LCDW, 2500$3000 \mathrm{~m}$ ) under the influence of westerly winds (Figure 2) (Sloyan and Rintoul, 2001). 
Upper Circumpolar Deep Water and LCDW become oxygenated through atmospheric exchanges when they reach the surface. Then, they are advected and subducted northward, feeding the AAIW and SAMW (Talley, 2013). Of the two water masses, AAIW is volumetrically the largest and dominates the oxygen supply to the ocean interior at low latitudes (Piola and Georgi, 1982). Bostock et al.(2013) showed that there are three types of AAIW present around New Zealand (Figure 11. There is a southern source AAIW, formed locally in the southwest Pacific sector of the Southern Ocean as well as an AAIW coming from the southeast Pacific via the South Pacific gyre. Finally, the third type, which is present in the Tasman Sea, is a mixture between the AAIW from the southeast Pacific source and surface waters from the Tasman Sea. Because AAIW has an essential role in ventilating the ocean interior, modelling studies have focused on AAIW to predict future oxygen variations (Sallee et al. 2010; Rintoul and Bullister, 1999: Downes et al. 2009). However, large uncertainties remain about the mechanisms

40 driving AAIW formation in the modern ocean (Bostock et al. 2013). Therefore, more work needs to be done in order to understand how our changing climate will influence AAIW formation and its oxygenation role.

A precise historical knowledge of how AAIW responded to past climatic forcing is essential to help understand how AAIW formation will change in the future. Hence, the reconstruction of past variations in oxygenation may be useful to better predict future oxygen changes in the Southern Ocean. Previous studies provided conflicting results regarding the AAIW geometry in the Pacific sector of the Southern Ocean between glacial and interglacial periods. Using sponge $\delta^{30} S i$ Rousseau et al. 2016) or a combination of benthic foraminiferal $\delta^{18} O$ and $\delta^{13} C$ (Elmore et al. 2015, Pahnke 50 and Zahn, 2005, Ronge et al., 2015), several authors reported AAIW contraction during glacial periods in the southwest Pacific sector of the Southern Ocean. They proposed that this AAIW contraction decreased the ventilation at intermediate depths. However, other authors reported increased ventilation at intermediate depths in the southeast Pacific sector of the Southern Ocean (along the Chilean margin) during the last ice 55 age (Muratli et al. 2009). They attributed this increased ventilation to greater AAIW formation. Based on a large scale data compilation, Jaccard and Galbraith (2012) and Jaccard et al. (2014) showed that intermediate depths of the Pacific Ocean were 

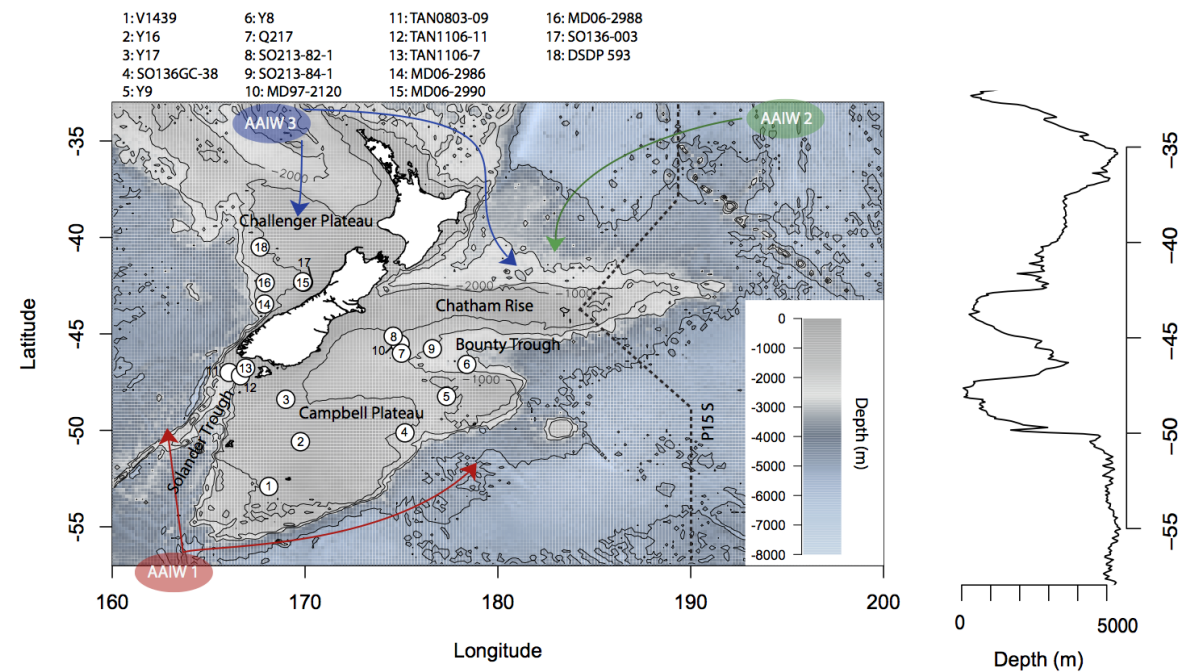

Figure 1: Map of the bathymetry of the New Zealand region as well as the sediment core locations on the left side. The present AAIW circulation is also shown (Chiswell et al. 2015). Three different AAIW types are present in the New Zealand region: AAIW 1 is a southern source AAIW, formed locally in the southwest Pacific sector of the Southern Ocean. AAIW 2 comes from the southeast Pacific via the South Pacific gyre. AAIW 3 is a mixture between the AAIW from the southeast Pacific source and surface waters from the Tasman Sea. The position of the P15S section used in Figure 2 is also represented. On the right side is shown the bathymetric transect from $180^{\circ} \mathrm{W}$.

generally better oxygenated during the Last Glacial Maximum (LGM) compared to the Holocene, while abyssal waters remained poorly ventilated. In the rest of the Southern Ocean, several studies also showed a poorer ventilation during the LGM compared to the Holocene (Wagner and Hendy, 2017, Lu et al., 2016; Frank et al., 2000, Jaccard et al. 2016); however, a general lack of data limits interpretations for this region. Consequently, uncertainties remain about past oxygen variations in the Pacific sector of the Southern Ocean. In particular, redox-sensitive metal proxies of bottom water oxygen have not been applied yet in the southwest Pacific.

In this study we aim to reconstruct the variations in the oxygen content of the intermediate waters of the southwest Pacific sector of the Southern Ocean, between the LGM and the Holocene. This region is of particular interest because parts of the shallow plateaux surrounding New Zealand are bathed by AAIW and are therefore ideal 


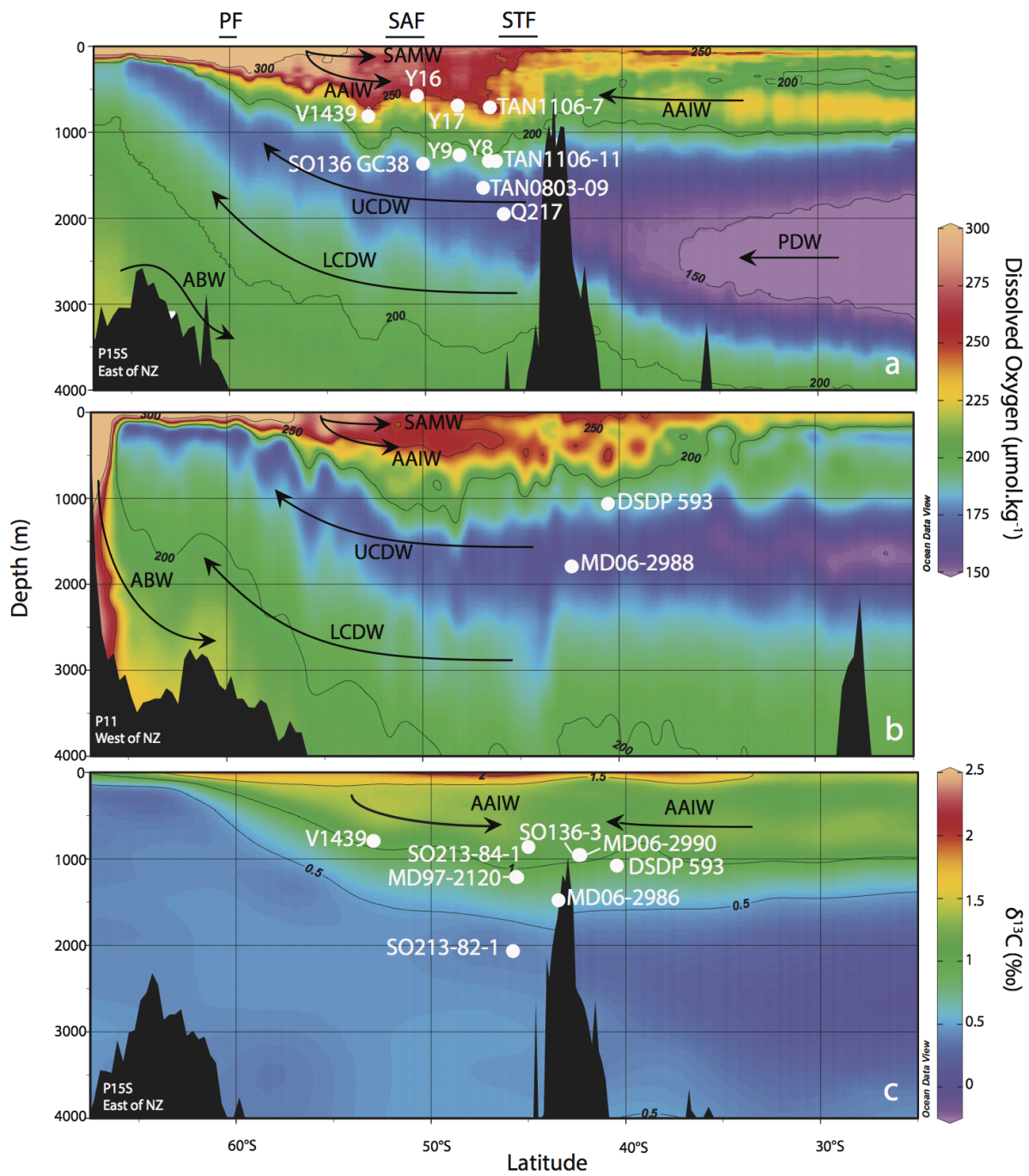

Figure 2: Oceanographic settings of the New Zealand region. Dissolved oxygen concentrations from the P15S (a) and P11 (b) sections (WOCE). The positions of the sediment cores analysed (aU, aRe) on the Campbell and Challenger plateaux are represented on the top and bottom panels respectively. (c) Carbon isotope composition of Dissolved Inorganic Carbon $\left(\delta^{13} D I C\right)$ from the P15S section of the WOCE. The positions of the sediment cores from which benthic foraminifera $\delta^{13} C$ were used in this study were added, although some of these cores are from the Tasman Sea, the $\delta^{13} C$ is assumed to be similar due to the relatively similar oxygen profiles in A and B. A simplified Southern Ocean circulation is shown from Talley (2013). The northern and southern AAIW sources are represented from Bostock et al. (2013). Graphs were plotted using Ocean Data View (Schlitzer 2017) 
to investigate AAIW changes (Figure 1, and 2) (Bostock et al., 2013; Forcén-Vázquez et al. 2017; Chiswell et al. 2015).

To this end, the authigenic Uranium (aU) and Rhenium (aRe) contents of 12 sediment cores from the New Zealand region were analysed (Campbell Plateau, Challenger Plateau, Bounty Trough) (Figure 1, 2, Table 1). The solubility of $U$ and Re in seawater

75 is dependent on the seawater oxygen concentration. When the dissolved oxygen concentration decreases, $\mathrm{U}$ and $\mathrm{Re}$ are reduced from their soluble forms $\left(\mathrm{UO}_{2}\left(\mathrm{CO}_{3}\right)_{3}\right)^{4-}$ , $\mathrm{U}(\mathrm{OH})_{4}$ and $\left.\mathrm{ReO}_{4}^{-}\right)$to insoluble forms $\left(\mathrm{UO}_{2(s)}\right.$ and $\left.\mathrm{ReO}_{2} \cdot 2 \mathrm{H}_{2} \mathrm{O}\right)$. This causes aU and aRe solid phases to accumulate in the sediments (Colodner et al., 1993, Morford and Emerson, 1999, Tribovillard et al., 2006, Crusius et al., 1996). This relationship

so between aU and aRe sediment enrichments and oxygen concentration is not linear and displays more of a threshold response (Zheng et al. 2002a b, McManus et al., 2005, 2006). Consequently, aU and aRe concentration variations in sediment are a semiquantitative proxy for oxygenation changes. In the Southern Ocean, previous studies have reported that low concentrations of aU and aRe in sediments, less than $1 \mathrm{mg} / \mathrm{kg}$ and

${ }_{85} 5 \mu \mathrm{g} / \mathrm{kg}$ respectively, correspond to well oxygenated waters, while high concentrations of aU and aRe, around $4 \mathrm{mg} / \mathrm{kg}$ and $20 \mu \mathrm{g} / \mathrm{kg}$ respectively, correspond to water with low oxygen content, without necessarily reaching anoxia (Chase et al., 2001; Muratli et al., 2009; Chase et al., 2003, Hayes et al., 2014, Gottschalk et al., 2016; Jaccard et al. 2016). In order to identify potential drivers of oxygen variations, circulation

90 changes were also reconstructed using available stable carbon isotopes from benthic foraminifera ( $\delta^{13} C$ benthic) from 8 sediment cores in the studied region (Figure 1,2 , Table 1). 


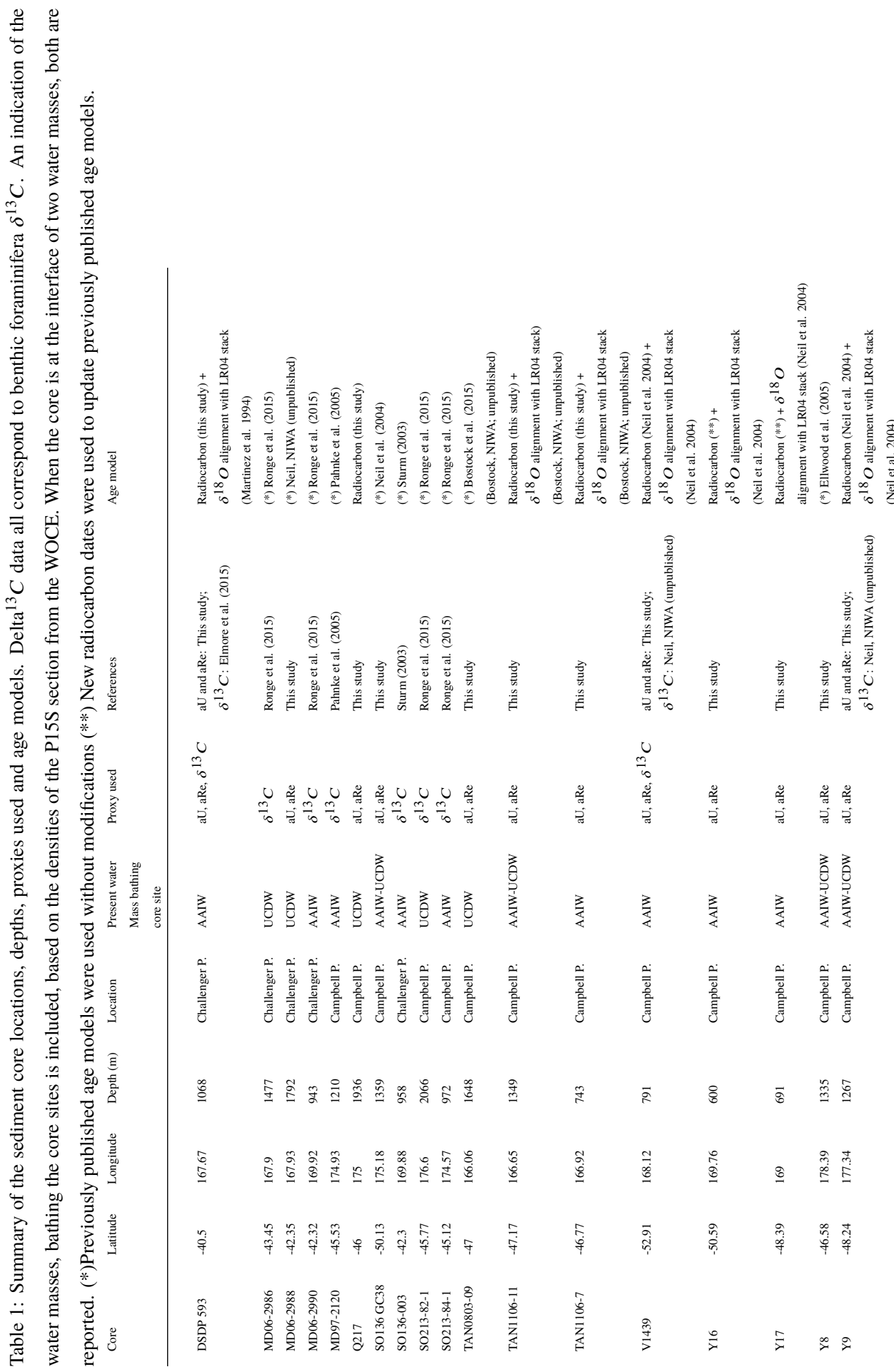




\section{Methods}

\subsection{Age models}

Previously published age models were used without modifications for several sediment cores in this study (Table 1). For the other cores, mixed planktonic foraminiferal radiocarbon data were used to update or to construct new age models. The new radiocarbon measurements were conducted by the ANSTO Science Institute (Lucas Heights, Australia) using an accelerator mass spectrometer (AMS). All AMS dates (new and pre-existing) were calibrated with the MARINE13 calibration curve (Reimer et al., 2013) using the OxCal 4.2 platform (Ramsey, 2009) and a modelled local reservoir age of 500 years (Skinner et al. 2017). When foraminiferal $\delta^{18} O$ were available (Table 11, the radiocarbon and foraminiferal $\delta^{18} O$ were combined to construct/update the age models. The radiocarbon dates were used as tie points, and correlated the $\delta^{18} O$ records to the LR04 stack using the Analyseries software (Paillard et al., 1996). Radiocarbon ages and uncertainties used to develop new age models are presented in Table 2

\subsection{Sediment preparation and digestion}

Sixty mg of freeze-dried and homogenized sediments were digested in a mix of $\mathrm{HCl}, \mathrm{HNO}_{3}$ and $\mathrm{HF}$ using a pressure-assisted microwave (Milestone Ethos SK-12 microwave oven, Milestone, Shelton, CT, USA). The sample preparation has been described in detail previously in Durand et al. (2016).

\subsection{Thorium, Uranium and Rhenium Analysis}

The day prior to analysis, samples were heated on a hot plate at $60^{\circ} \mathrm{C}$ for 24 hours and then diluted by a factor of 10 with milli-Q water. At this stage Indium $\left({ }^{115} \mathrm{In}\right)$ was added as an internal standard. An ELEMENT 2 Sector Field Inductively Coupled PlasmaMass spectrometer (ICP-MS) from Thermo Fischer Scientific (Bremen, Germany) was used in low resolution $(\mathrm{m} / \Delta \mathrm{m} \approx 400)$ to measure $R e$, Thorium $(\mathrm{Th})$ and $U$ concentrations, with isotopes ${ }^{115} \mathrm{In},{ }^{185} \mathrm{Re},{ }^{232} \mathrm{Th}$ and ${ }^{238} \mathrm{U}$ monitored. An external calibration method was used for the elemental quantification. The calibration solutions were prepared daily from $100 \mu \mathrm{g} / \mathrm{mL}$ standard solutions (QCD Analysts, Spring Lake, NJ, USA). Further 
Table 2: Radiocarbon ages and uncertainties used to develop new age models.

\begin{tabular}{|c|c|c|}
\hline Cores & Uncalibrated ages BP (years) & Calibrated age BP (years) \\
\hline \multirow[t]{4}{*}{ DSDP 593} & $6940 \pm 70$ at $0.5 \mathrm{~cm}$ & $7364 \pm 274$ \\
\hline & $10430 \pm 45$ at $15.5 \mathrm{~cm}$ & $11881.5 \pm 427$ \\
\hline & $16980 \pm 70$ at $27.5 \mathrm{~cm}$ & $20033 \pm 451$ \\
\hline & $19750 \pm 90$ at $45.5 \mathrm{~cm}$ & $23346 \pm 538$ \\
\hline Q217 & $9430 \pm 45$ at $24.5 \mathrm{~cm}$ & $10213 \pm 254$ \\
\hline \multirow[t]{3}{*}{ TAN1106-11 } & $1570 \pm 60$ at $1.5 \mathrm{~cm}$ & $1999 \pm 259$ \\
\hline & $11030 \pm 70$ at $61.5 \mathrm{~cm}$ & $12462 \pm 310$ \\
\hline & $13690 \pm 60$ at $121.5 \mathrm{~cm}$ & $16103 \pm 519$ \\
\hline \multirow[t]{3}{*}{ TAN1106-7 } & $5455 \pm 35$ at $1.5 \mathrm{~cm}$ & $5816 \pm 110$ \\
\hline & $10070 \pm 60$ at $41 \mathrm{~cm}$ & $11209 \pm 631$ \\
\hline & $16260 \pm 80$ at $111 \mathrm{~cm}$ & $19228 \pm 510$ \\
\hline \multirow[t]{3}{*}{ Y16 } & $4280 \pm 40$ at $0.5 \mathrm{~cm}$ & $4405 \pm 255$ \\
\hline & $7400 \pm 40$ at $24.5 \mathrm{~cm}$ & $7773 \pm 274$ \\
\hline & $36320 \pm 290$ at $48.5 \mathrm{~cm}$ & $40504 \pm 1254$ \\
\hline \multirow[t]{3}{*}{ Y17 } & $3460 \pm 30$ at $0.5 \mathrm{~cm}$ & $3302 \pm 189$ \\
\hline & $7755 \pm 40$ at $36.5 \mathrm{~cm}$ & $8082 \pm 164$ \\
\hline & $18360 \pm 80$ at $56.5 \mathrm{~cm}$ & $21762 \pm 472$ \\
\hline
\end{tabular}


details concerning sample handling procedures, as well as the instrument operating conditions can be found in Durand et al. (2016). The long-term reproducibility of the method was tested over multiple digestions and analyses of D-178, a surface sediment from the Campbell Plateau. Across the 19 measurements over a three month period, standard deviations observed for Re, Th and U were less than 10\% (Durand et al.,2016).

\subsection{Calculation of authigenic Uranium and Rhenium concentrations}

The total $\mathrm{U}$ and $\mathrm{Re}$ concentrations in the sediments represent input from both the land (detrital $U$ and $R e$ ) and the water (authigenic $U$ and Re). Authigenic $U$, and Re (aU and $\mathrm{aRe}$ ) concentrations were estimated as follows (M indicates Metal):

$$
M_{\text {authigenic }}=M-\left(\frac{M}{T h}\right)_{c c} \cdot T h_{\text {total }}
$$

The mean continental crust $(\mathrm{cc})$ ratios $(U / T h)_{c c}$ and $(R e / T h)_{c c}$ used were 0.23 and $33 e^{-6}$ respectively (Rudnick and Gao, 2003). Mean continental crust ratios were compared to the records available in the New Zealand region (EarthChem database) and the averaged crust ratios were found to be representative for the New Zealand region. Overall, the detrital fraction represented approximately 10 to $25 \%$ of the total $U$ for the cores located on the Campbell Plateau, and 60 to $70 \%$ of the total $U$ for the cores located in the Solander Trough region. The detrital Re corrections were less than 1\% of the total Re for the cores located on the Campbell Plateau and up to $8 \%$ for the cores in the Solander Trough region.

\section{Results}

In the following sections the LGM and Holocene time slices have been defined as intervals ranging between 25 to $18 \mathrm{ka}$ and 12 to $5 \mathrm{ka}$, respectively.

\subsection{Authigenic Uranium and Rhenium}

The sedimentary aU and aRe concentrations were higher during the LGM compared to the Holocene in the cores located on the Campbell and Challenger plateaux (Figure 145 3). On the Campbell Plateau, the aU concentrations in V1439 were $4.5 \mathrm{mg} / \mathrm{kg}$ higher 
during the LGM compared to the Holocene. However, for the other sites on the Campbell Plateau (Y16, Y17, SO136GC-38, Y9), the aU concentrations were only approximatively $3 \mathrm{mg} / \mathrm{kg}$ higher during the LGM. For the same cores aRe concentrations were generally 10 to $20 \mu \mathrm{g} / \mathrm{kg}$ higher during the LGM. On the Challenger Plateau (cores MD06-2988 and DSDP 593) the aU and aRe concentrations were on average $2 \mathrm{mg} / \mathrm{kg}$ and $7.5 \mu \mathrm{g} / \mathrm{kg}$ higher respectively, during the LGM relative to the Holocene. Overall, larger aU and aRe concentration differences are observed between the LGM and the Holocene on the Campbell Plateau compared to the Challenger Plateau.

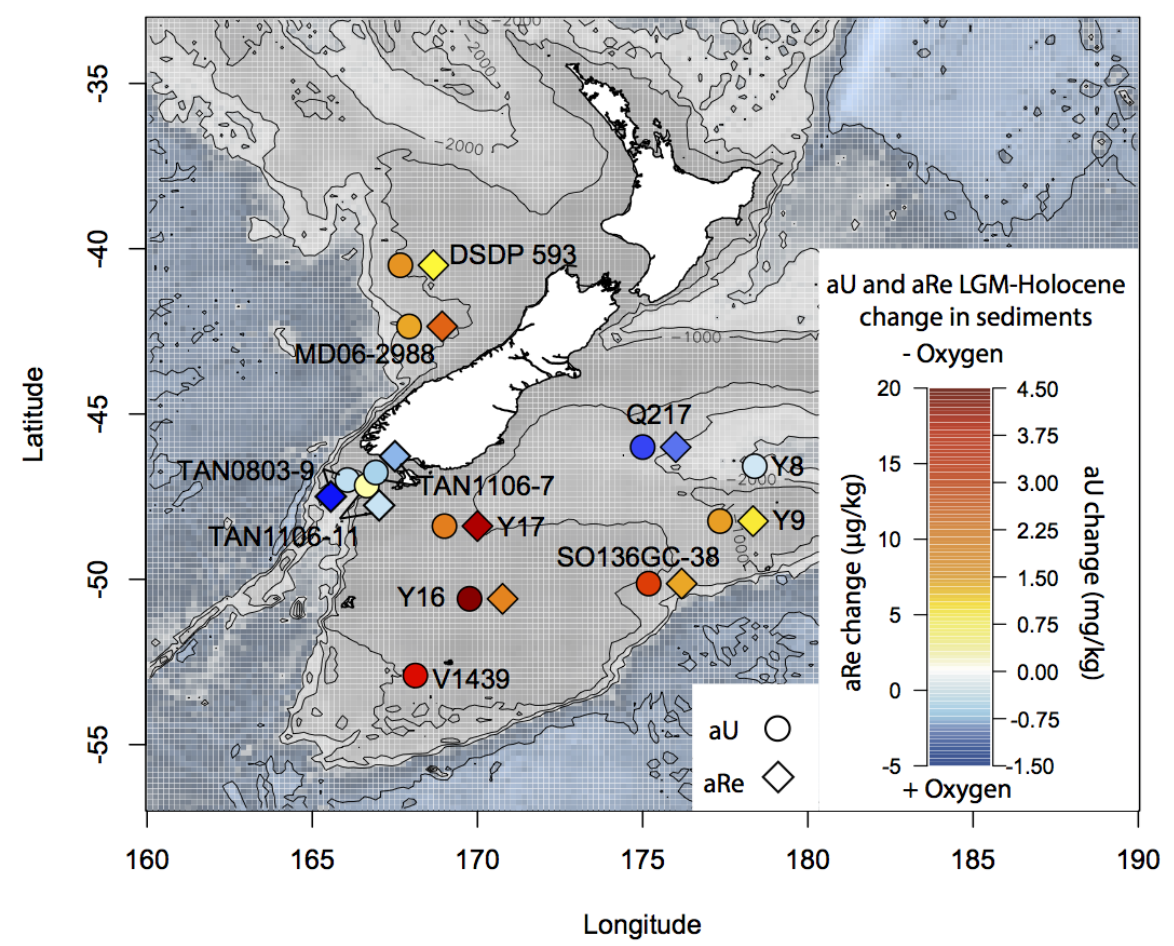

Figure 3: Difference in authigenic U and Re (aU: dots and aRe: diamonds) between the LGM (18-25 ka) and the Holocene (5-12 ka). Positive values indicate higher aU and aRe concentrations in the sediment during the LGM, and lower inferred bottom water oxygen concentrations.

Q217 as well as the cores located in the Solander Trough, which sits between the 
Macquarie ridge and the Campbell Plateau (TAN1106-11, TAN1106-07, TAN0803-

09) had slightly lower aU and aRe concentrations during the LGM compared to the Holocene. However, the differences for these five cores were modest: aU and aRe differences between the LGM and the Holocene never exceeded $1.5 \mathrm{mg} / \mathrm{kg}$ and $5 \mu \mathrm{g} / \mathrm{kg}$ respectively. Y8 did not contain any aU during the LGM or the Holocene.

To help determine whether the inferred oxygen changes were primarily controlled by changes in ocean circulation the existing benthic carbon isotope data for this region were compiled (both published and unpublished). The benthic foraminifera $\delta^{13} C$ values observed for the Challenger and Campbell plateaux during the Holocene agree well with the modern Dissolved Inorganic Carbon (DIC) values (Figure 1 and 4).

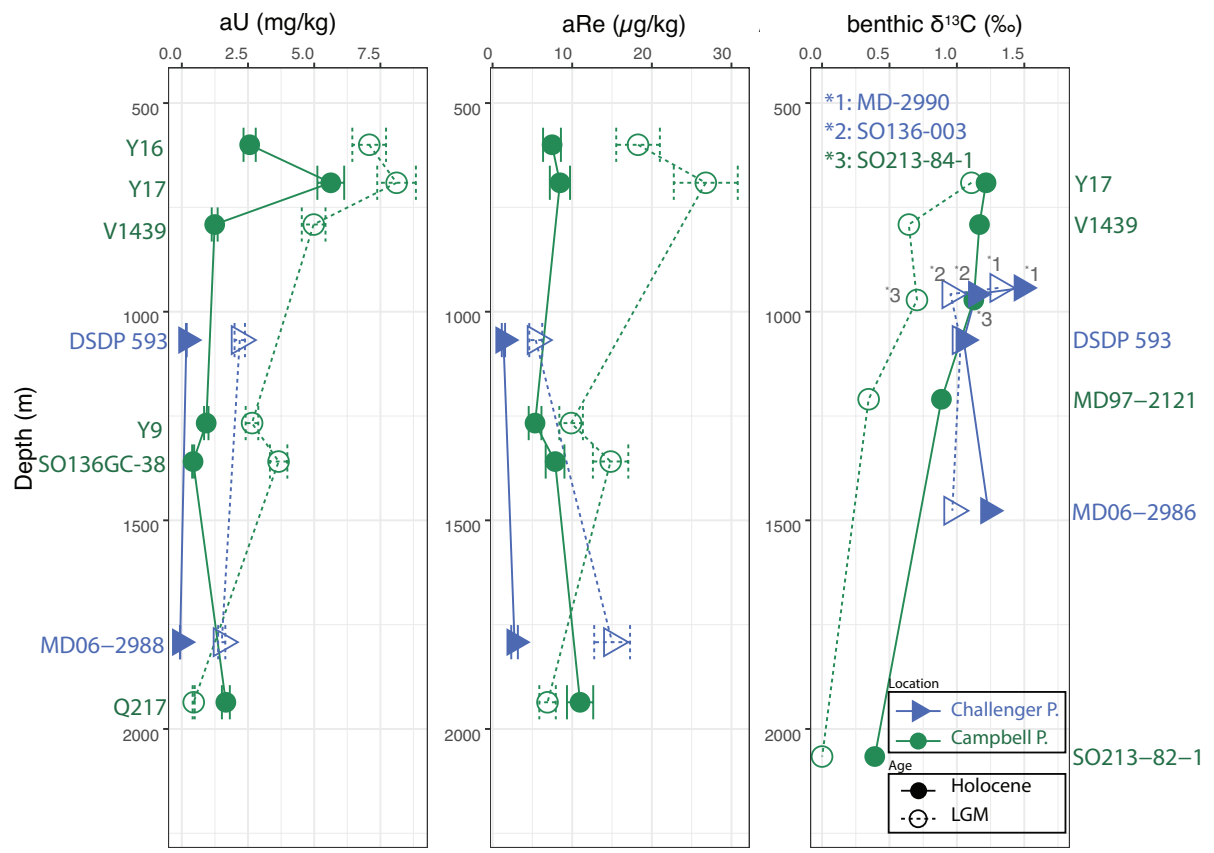

Figure 4: Authigenic $\mathrm{U}$ and $\mathrm{Re}$ (aU and aRe) and benthic foraminifera $\delta^{13} \mathrm{C}$ as a function of core depth for LGM (dashed; 18-25 ka) and Holocene (plain; 5-12 ka) time slices on the Challenger (blue triangles) and Campbell (green circles) plateaux. Standard errors are reported for aU and aRe corresponding to the method precision (See Durand et al. (2016)). Y8 and the Solander Trough sites were excluded because of the potential "burn-down" affecting Y8 and EP changes affecting the Solander Trough sites. 
The benthic foraminifera $\delta^{13} C$ variations with depth show a dramatic regional difference between the Campbell and Challenger plateaux (Figure 4). On the Challenger Plateau, similar $\delta^{13} C$ values are observed during the LGM and the Holocene at all depths. However, on the Campbell Plateau, below $600 \mathrm{~m}$, cores show $\delta^{13} \mathrm{C}$ increases

$170 \quad(0.4-0.85 \%)$ between the LGM and the Holocene that are larger than the whole-ocean glacial-interglacial $\delta^{13} C$ change (0.34\%, Figure 44 (Peterson et al. 2014). Cores on the Campbell Plateau above 600m (MD97-2109, SO13-061 and Y17) show no $\delta^{13} C$ change between the LGM and the Holocene (Figure 4).

\section{Discussion}

At typical AAIW depths (500-1200 m) on the Campbell and Challenger plateaux, the $\mathrm{aU}$ and aRe concentrations were higher during the LGM than in sediments presently bathed by UCDW (1500-2500 m). In contrast, waters of the Solander Trough region (where TAN1106-07, TAN1106-11 and TAN0803-9 were retrieved) were depleted in $\mathrm{aU}$ and aRe during the LGM compared to the Holocene. If the observed changes in redox sensitive metal concentrations are interpreted in terms of oxygenation changes at the water-sediment interface, these data suggest the intermediate depths above the Campbell and Challenger plateaux were depleted in oxygen during the LGM compared to the Holocene. As several other factors may drive changes in authigenic metal (aM: $\mathrm{U}$ and $\mathrm{Re}$ ) concentrations, we address each of these in turn.

Sedimentation rate changes can influence the incorporation of aM in the sediments independently of any changes in bottom water oxygenation changes by diluting (increased sedimentation) or concentrating (decreased sedimentation) the aM (Tribovillard et al. 2006). Table 3 compiles sedimentation rates at different sites during the Holocene and the LGM. Overall, no coherent pattern of sedimentation rate changes between the LGM and the Holocene can explain the aU and aRe glacial enrichments observed in the New Zealand region. Three cores had moderately higher sedimentation rates during the LGM compared to the Holocene. Three cores had lower sedimentation rates during the LGM compared to the Holocene and two cores had no change. Only TAN0803-09 and TAN1106-11 had noticeably higher sedimentation rates during the 
LGM compared to the Holocene. However, these two cores had higher aU and aRe concentrations during the Holocene compared to the LGM. Therefore, we conclude that the aU and aRe variations observed in this study are not primarily controlled by changes in sediment accumulation.

Table 3: Sedimentation rates during the Holocene and the LGM at different core sites. MD06-2988 and Q217 sedimentation rates were not calculated due to insufficient radiocarbon ages.

\begin{tabular}{lll} 
Core & Holocene sed.rate $(\mathrm{cm} / \mathrm{ka})$ & LGM sed.rate $(\mathrm{cm} / \mathrm{ka})$ \\
\hline & & \\
DSDP 593 & 3.3 & 3.3 \\
SO136GC-38 & 1.7 & 3.3 \\
TAN0803-09 & 4.9 & 19.8 \\
TAN1106-07 & 7.4 & 8.7 \\
TAN1106-11 & 5.7 & 16.2 \\
V1439 & 2.9 & 3.9 \\
Y8 & 3.9 & 3.9 \\
Y9 & 6 & 1.2 \\
Y16 & 7.2 & 1 \\
Y17 & 7.5 & 1.5
\end{tabular}

Similarly, drastic changes in sedimentary redox conditions can lead to post-depositional remobilization of $\mathrm{U}$ and $\operatorname{Re}$ ("burn-down"), potentially complicating paleoceanographic interpretations (Crusius and Thomson, 2000, 2003). Particularly, because most sites in this study have low sedimentation rates (Table 3) they can be affected by remobilisation. To limit the impact of remobilisation on aU and aRe, time slices were defined across large time intervals. However, for $\mathrm{Y} 8$, the absence of aU across all samples suggests that this site may have experienced a "burn-down" of aU deposited during the LGM. This "burn-down" would have occurred because of the deepening of the AAIW-UCDW boundary between the LGM and the Holocene (see section 4.2). At other sites, we suggest that oxygenation changes have driven the aU and aRe variations observed. The coherent spatial and temporal aM variations between the sites despite differences in 
Futhermore, the range of aU and aRe concentrations observed in the sediments from our study is consistent with what has been reported previously in the rest of the Southern Ocean with concentrations ranging from 0 to $5 \mathrm{mg} / \mathrm{kg}$ and 0 to $20 \mu \mathrm{g} / \mathrm{kg}$ for aU and ${ }_{0}^{\mathrm{a} R e}$ respectively (Chase et al., 2001; Muratli et al., 2009; Chase et al., 2003; Hayes

sedimentation rates, show that remobilisation is not a dominant driver of aM variations. et al., 2014, Gottschalk et al., 2016, Jaccard et al., 2016). Finally, the similar behaviour between $\mathrm{aU}$ and aRe enrichments increases the confidence that oxygen changes drove the aM concentration variations at all sites except Y8 (Figures 3 and 4).

The following sections discuss the mechanisms that could possibly have driven the substantial oxygen changes inferred from aU and aRe variations between the LGM and the Holocene.

\subsection{Changes in export production as potential drivers of oxygenation changes}

Since labile organic matter is supplied by export production (EP), an increase in EP leads to oxygen depletion in the ocean interior. As a consequence, increased EP in the New Zealand region during the LGM could potentially explain aU and aRe enrichments in the sediments of the Challenger and Campbell plateaux. Durand et al. (2017) used 230-Thorium normalised biogenic fluxes from four cores used in this study (DSDP 593, TAN0803-09, SO136GC-38 and Y9) to reconstruct EP changes in the New Zealand region since the LGM. They showed that EP stayed low and rather constant over the Campbell and Challenger plateaux since the LGM. This result is in agreement with previous findings (Ellwood et al., 2005) and rules out increased organic matter remineralisation as a major driver of oxygen changes between the LGM and the Holocene over the Campbell and Challenger plateaux. However, at site TAN0803-09, Durand et al. (2017) found that EP was greater during the deglaciation and Holocene compared to the LGM. This was likely caused by a southward shift of the highly productive subtropical front over the core location during the deglaciation (12-18 ka) (Bostock et al., 2015). Therefore, we suggest that the high aU and aRe values observed during the Holocene for the three Solander Trough cores may have been influenced by increased EP due to changes in ocean circulation. 


\subsection{Shallower AAIW over the Campbell Plateau during the LGM}

By plotting the temporal aU and aRe variations along depth, it is apparent that depth and thus the water mass geometry has been a driver of change on the Campbell Plateau between the LGM and the Holocene (Figure 4 , S1). On the Campbell and Challenger plateaux, at intermediate depths $(500-1200 \mathrm{~m})$, the aU and aRe concentrations were higher during the LGM than in sediments presently bathed by UCDW (1500-2500 m).

Plateau during the Holocene compared to the LGM could be partly explained by a deepening of the AAIW-UCDW boundary between the LGM and the Holocene. And if this deepening was associated with a lower UCDW oxygen content during the LGM compared to the Holocene. Decrease in ventilation and thus subsequent reduction in oxygen content of UCDW had been reported previously in the New Zealand region (Skinner et al. 2015). During the Holocene, this deepening would have brought oxygenated AAIW to sites that were bathed by oxygen-depleted UCDW during the LGM. Such changes could help explain the aU and aRe variations at core sites V1439, SO136GC38 and Y9, Y16 and Y17. Similarly, deepening the UCDW-LCDW boundary between the LGM and the Holocene could explain the higher aM concentrations observed during the Holocene at deeper site, Q217, because UCDW has a lower oxygen concentration than LCDW (Figure 2).

Several studies using benthic foraminifera $\delta^{13} C$ variations in sediment cores concluded that the AAIW-UCDW boundary deepened between the LGM and the Holocene in the Pacific sector of the Southern Ocean (Pahnke and Zahn, 2005, Ronge et al., 2015). These conclusions are based on observations of lower benthic foraminifera $\delta^{13} C$ values during the LGM compared to the Holocene in MD97-2120 (Figure 4). Even though several factors such as differences in biological productivity or air-sea gas exchange can compromise the use of $\delta^{13} C$ as a circulation proxy (Schmittner et al. 2013, 2017), in ${ }_{265}$ this region, these studies concluded that circulation is the main driver of $\delta^{13} C$ changes (Ronge et al. 2015, Pahnke and Zahn 2005. Therefore, because the $\delta^{13} C$ of AAIW $(\approx 1.5 \%)$ is higher than that of UCDW $(<0.5 \%)$, these studies concluded that UCDW and not AAIW was bathing the location of MD97-2120 (1210 m) during the LGM.

The benthic $\delta^{13} C$ data from the Campbell Plateau compiled here agree with the 
was shallower during the LGM compared to the Holocene (Figure 4). The $\delta^{13} C$ increases observed at V1439 and MD97-2120 between the LGM and the Holocene cannot only be driven by the glacial-interglacial reservoir change but can be explained by the deepening of the AAIW-UCDW boundary between the LGM and the Holocene. a decrease in the AAIW formation rate (Figure 5). A decrease in the AAIW production could have resulted from a northward shift of the westerlies towards lower latitudes (Voigt et al., 2015, Downes et al., 2011), stronger Split Jet or a negative Southern Annular Mode (SAM) (Chiang et al., 2018). Some authors also suggested that during Zahn, 2005), thereby decreasing AAIW density, limiting its subduction depth (Ronge et al. 2015).

\subsection{Change in the AAIW source reaching the Challenger Plateau}

On the Campbell Plateau both the higher concentrations of aU and aRe and lower 295 $\delta^{13} C$ during the LGM suggest that AAIW was deeper during the Holocene compared to the LGM (Figures 3, 4). However, the single mechanism of deepening the AAIWUCDW boundary between the LGM and the Holocene cannot explain all of the data presented in this study. On the Challenger Plateau, aM data show lower oxygenation during the LGM relative to the Holocene, as on the Campbell Plateau. However, in 


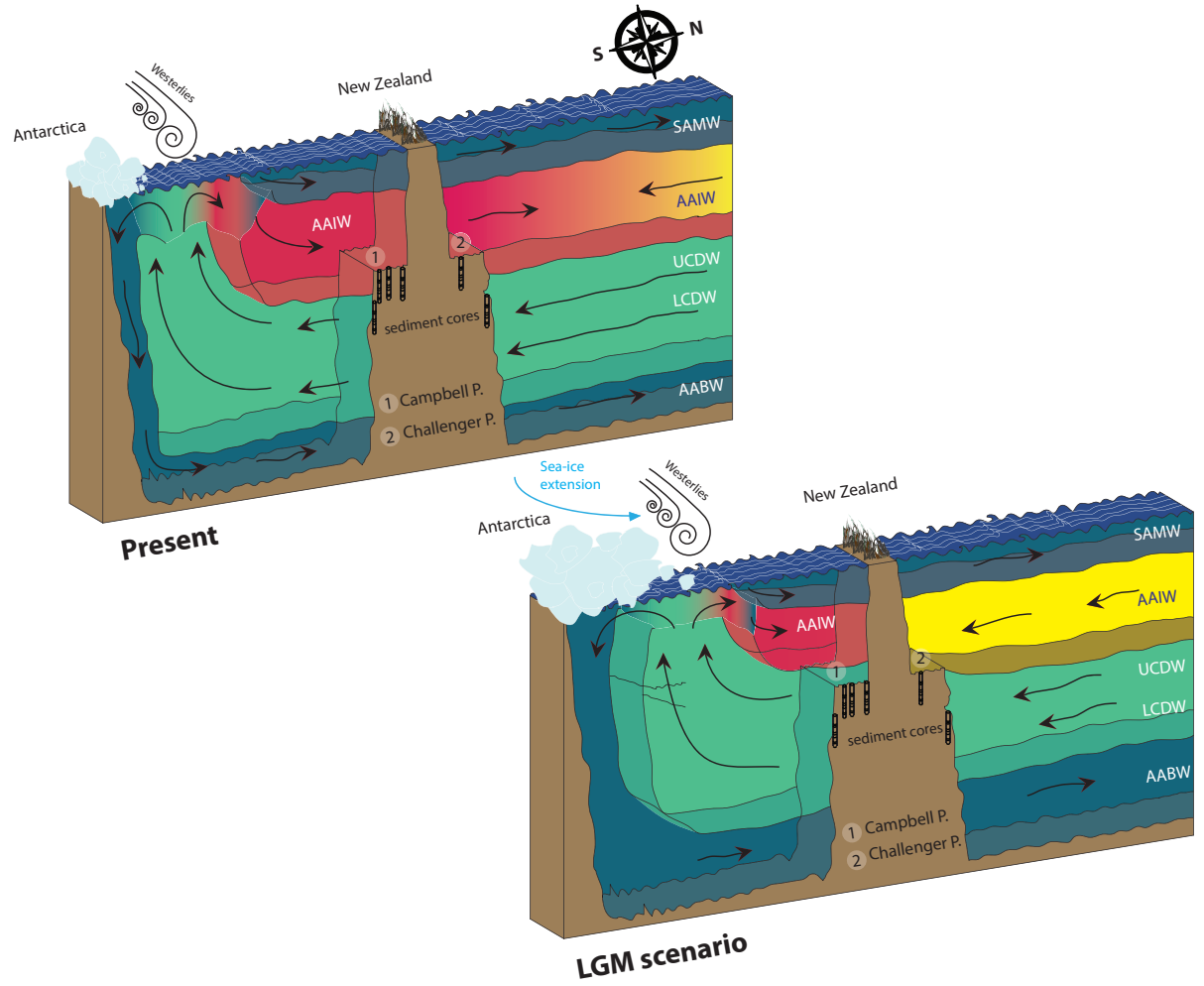

Figure 5: Schematics of the scenario that can explain the differences between the Campbell (1) and Challenger (2) plateaux $\delta^{13} C$ and redox-sensitive metal data. On the top panel, modern circulation. On the bottom panel the southern source AAIW (red) shoaled and left the Campbell Plateau partly bathed by oxygen depleted UCDW, while the lower oxygen northern source AAIW (yellow) intensified and bathed the Challenger Plateau and shallow parts of the Campbell Plateau.

contrast to the cores on the Campbell Plateau, our compilation of $\delta^{13} C$ data from cores DSDP 593, MD06-2990, SO136-003 and MD06-2986 on the Challenger Plateau shows very little difference in $\delta^{13} C$ between the LGM and the Holocene (Figure 4). Indeed, if anything, after the application of a whole-ocean $\delta^{13} \mathrm{C}$ change (Figure S2,,$\delta^{13} \mathrm{C}$ on the Challenger plateau at intermediate depths is slightly higher during the LGM relative to the Holocene. These data are inconsistent with the deepening of AAIWUCDW boundary between the LGM and the Holocene, discussed previously for the Campbell Plateau. Instead, the $\delta^{13} C$ data suggest that AAIW uninterruptedly overlaid the Challenger Plateau since the LGM. 
A change in the AAIW source bathing the New Zealand region could explain the

5). As mentioned earlier, there are three types of AAIW present around New Zealand (Figure 1) (Bostock et al., 2013). In terms of oxygen concentrations, the southern sourced AAIW is younger and has higher oxygen content than the northern types (Chiswell et al. 2015); however, in terms of $\delta^{13} C$ the three AAIW types have similar and Campbell plateaux (Chiswell et al. 2015). However, it is possible that during the LGM the region was bathed by and a northern source AAIW. Muratli et al. (2009) argued that the production of AAIW in the southeast Pacific was higher during the LGM. The southeast Pacific AAIW is the source of the northern types AAIW, both southeast Pacific during the LGM could have resulted in the expansion of the northern types of AAIW in the New Zealand region. In this case, expanded northern type AAIW could have bathed the Challenger Plateau (Figure 5).

\subsection{Implications and perspectives}

The glacial deoxygenation observed here is at odds with the general notion that AAIW ventilation at intermediate depths was greater during the LGM in the Southern Ocean (Jaccard et al., 2014). This increased ventilation is thought to have resulted from colder temperatures, which increase the oxygen content of AAIW, and stronger westerly winds that are thought to enhance AAIW formation (Downes et al., 2009, 2010). Moreover, the results from this study are also in opposition to those of Muratli et al. (2009) who, using redox sensitive proxies, reported higher oxygen content at intermediate depths in the southeast Pacific sector of the Southern Ocean (along the Chilean Margin). Therefore, these opposing patterns stress the complex responses of AAIW ventilation to climate forcing. In particular, the results presented here highlight

sides of the Pacific sector of the Southern Ocean. A recent study revealed a similar ¡xygenation asymmetry associated with weaker Split Jet and positive SAM (Chiang et al., 2018). In their study, they observed increased oxygenation in the South Pacific 
globally, linked with increased AAIW formation during weaker Split Jet and/or positive SAM, except in a small zone along the Chilean Margin where the cores studied by Muratli et al. (2009) are located. This deoxygenation along the Chilean Margin originates from the North and is associated with surface undercurrent and PDW and not from a reduced AAIW formation (Chiang et al. 2018). Therefore, it is possible that weaker Split Jet and/or positive SAM developed since the LGM, resulting in increased AAIW formation and increased oxygenation in the South Pacific globally except in a small zone along the Chilean margin where an opposite pattern emerged. Future work will need to address this discrepancy. New redox-metal measurements from multiple sediment cores from the southeast Pacific, spanning a wider range of locations and depths, could help to solve this question. So far AAIW oxygenation reconstruction in this region is based on a limited record (three sites) spanning a small depth range $(\approx 500$ m) (Muratli et al., 2009). Being able to reconstruct AAIW ventilation and circulation is critical because AAIW plays an important role in sequestering greenhouse gas in the ocean interior (Sabine et al., 2004). Therefore, the reliability of future climate change scenarios depends on our ability to resolve how AAIW responds to climatic forcing.

\section{Conclusion}

In summary, this study shows that the intermediate depths of the Campbell and Challenger plateaux were less oxygenated during the LGM compared to the Holocene, while in the Solander Trough region no oxygenation change was observed between the LGM and Holocene. In the Solander Trough region this was likely partially caused by an increase in EP from the shifting of the subtropical front over the region during the deglaciation. On the Challenger Plateau, $\delta^{13} C$ variations show that AAIW continued overlaying the plateau. Therefore, we hypothesise that a change in the dominant AAIW source, from a southern source AAIW to a lower oxygen, northern source AAIW can explain these results. In contrast, a relatively shallower AAIW over the Campbell Plateau during the LGM compared to the Holocene, left deeper parts of the plateau bathed by the low oxygen UCDW. Finally, aU and aRe data suggest that UCDW oxygen content was lower during the LGM than it is presently. 


\section{Acknowledgements}

This work was supported by the Australia/New Zealand IODP Consortium (ANZIC), and by an ARC Future Fellowship awarded to Zanna Chase [grant number FT120100759]. Access to ICP-MS instrumentation was supported through ARC LIEF funds [grant number LE0989539]. Samuel L. Jaccard was funded by the Swiss National Foundation (grant PP00P2-144811). Radiocarbon analyses at ANSTO were supported by a AINSE grants ALNGRA11081 and ALNGRA14503. Helen Bostock is supported by COPR

375 funding from NIWA (New Zealand government). Thanks to IODP Kochi Core Center for access to the samples for DSDP 593.

\section{Database}

Pangaea database compiling the new data created during this work, including sample intervals and age models:

https://doi.pangaea.de/10.1594/PANGAEA.864666

\section{References}

Bograd, S.J., Castro, C.G., Di Lorenzo, E., Palacios, D.M., Bailey, H., Gilly, W., Chavez, F.P., 2008. Oxygen declines and the shoaling of the hypoxic boundary in the California Current. Geophysical Research Letters 35.

385 Bostock, H.C., Barrows, T.T., Carter, L., Chase, Z., Cortese, G., Dunbar, G.B., Ellwood, M., Hayward, B., Howard, W., Neil, H.L., Noble, T.L., Mackintosh, A., Moss, P.T., Moy, A.D., White, D., Williams, M.J.M., Armand, L.K., 2013. A review of the Australian-New Zealand sector of the Southern Ocean over the last 30 ka (AusINTIMATE project). Quaternary Science Reviews 74, 35-57. in the position of the Subtropical Front south of New Zealand since the last glacial period. Paleoceanography 30, 824-844. 
Chase, Z., Anderson, R.F., Fleisher, M.Q., 2001. Evidence from authigenic uranium for increased productivity of the glacial Subantarctic Ocean. Paleoceanography 16, $468-478$.

Chase, Z., Anderson, R.F., Fleisher, M.Q., Kubik, P.W., 2003. Accumulation of biogenic and lithogenic material in the Pacific sector of the Southern Ocean during the past 40,000 years. Deep Sea Research Part II: Topical Studies in Oceanography 50, 799-832.

Chiang, J.C.H., Tokos, K.S., Lee, S.Y., Matsumoto, K., 2018. Contrasting Impacts of the South Pacific Split Jet and the Southern Annular Mode Modulation on Southern Ocean Circulation and Biogeochemistry. Paleoceanography and Paleoclimatology $33,2-20$.

Chiswell, S.M., Bostock, H.C., Sutton, P.J., Williams, M.J., 2015. Physical oceanography of the deep seas around New Zealand: a review. New Zealand Journal of Marine and Freshwater Research 49, 1-32.

Colodner, D.C., Boyle, E.A., Edmond, J.M., 1993. Determination of rhenium and platinum in natural waters and sediments, and iridium in sediments by flow injection isotope dilution inductively coupled plasma mass spectrometry. Analytical Chemistry $65,1419-1425$.

Crusius, J., Calvert, S., Pedersen, T., Sage, D., 1996. Rhenium and molybdenum enrichments in sediments as indicators of oxic, suboxic and sulfidic conditions of deposition. Earth and Planetary Science Letters 145, 65-78.

Crusius, J., Thomson, J., 2000. Comparative behavior of authigenic Re, U, and Mo during reoxidation and subsequent long-term burial in marine sediments. Geochimica et Cosmochimica Acta 64, 2233-2242.

Crusius, J., Thomson, J., 2003. Mobility of authigenic rhenium, silver, and selenium during postdepositional oxidation in marine sediments. Geochimica et Cosmochimica Acta 67, 265-273. 
Diaz, R.J., Rosenberg, R., 2008. Spreading dead zones and consequences for marine ecosystems. Science 321, 926-929.

Downes, S.M., Bindoff, N.L., Rintoul, S.R., 2009. Impacts of climate change on the subduction of mode and intermediate water masses in the Southern Ocean. Journal of Climate 22, 3289-3302.

Downes, S.M., Bindoff, N.L., Rintoul, S.R., 2010. Changes in the subduction of Southern Ocean water masses at the end of the twenty-first century in eight IPCC models. Journal of Climate 23, 6526-6541.

Downes, S.M., Budnick, A.S., Sarmiento, J.L., Farneti, R., 2011. Impacts of wind stress on the Antarctic Circumpolar Current fronts and associated subduction. Geophysical Research Letters 38.

Durand, A., Chase, Z., Noble, T.L., Bostock, H.C., Jaccard, S.L., Kitchener, P., Townsend, A.T., Jansen, N., Kinsley, L., Jacobsen, G., Johnson, S., Neil, H., 2017. Export production in the New-Zealand region since the Last Glacial Maximum. Earth and Planetary Science Letters .

${ }_{435}$ Durand, A., Chase, Z., Townsend, A.T., Noble, T., Panietz, E., Goemann, K., 2016. Improved methodology for the microwave digestion of carbonate-rich environmental samples. International Journal of Environmental Analytical Chemistry 96, 119-136.

Ellwood, M.J., Kelly, M., Neil, H., Nodder, S.D., 2005. Reconstruction of paleo-particulate organic carbon fluxes for the Campbell Plateau region of southern New Zealand using the zinc content of sponge spicules. Paleoceanography 20.

Elmore, A.C., McClymont, E.L., Elderfield, H., Kender, S., Cook, M.R., Leng, M.J., Greaves, M., Misra, S., 2015. Antarctic Intermediate Water properties since $400 \mathrm{ka}$ recorded in infaunal (Uvigerina peregrina) and epifaunal (Planulina wuellerstorfi) benthic foraminifera. Earth and Planetary Science Letters 428, 193-203.

${ }_{445}$ Emerson, S.R., Bushinsky, S., 2014. Oxygen Concentrations and Biological Fluxes in the Open Ocean. Oceanography 27, 168-171. 
Forcén-Vázquez, A., Williams, M., Bowen, M., Carter, L., 2017. Campbell Plateau: A major control on the SW Pacific sector of the Southern Ocean circulation. ocean-scidiscuss.net .

450 Frank, M., Gersonde, R., van der Loeff, M.R., Bohrmann, G., Nurnberg, C.C., Kubik, P.W., Suter, M., Mangini, A., 2000. Similar glacial and interglacial export bioproductivity in the Atlantic sector of the Southern Ocean: Multiproxy evidence and implications for glacial atmospheric CO2. Paleoceanography 15, 642-658.

Gottschalk, J., Skinner, L.C., Lippold, J., Vogel, H., Frank, N., Jaccard, S.L., Waelbroeck, C., 2016. Biological and physical controls in the Southern Ocean on past millennial-scale atmospheric CO2 changes. Nature Communications 7, 11539.

Hayes, C.T., Martínez-Garcia, A., Hasenfratz, A.P., Jaccard, S.L., Hodell, D.A., Sigman, D.M., Haug, G.H., Anderson, R.F., 2014. A stagnation event in the deep South Atlantic during the last interglacial period. Science 346, 1514-1517.

460 Helm, K.P., Bindoff, N.L., Church, J.A., 2011. Observed decreases in oxygen content of the global ocean. Geophysical Research Letters 38.

Jaccard, S.L., Galbraith, E.D., 2012. Large climate-driven changes of oceanic oxygen concentrations during the last deglaciation. Nature Geoscience 5, 151-156.

Jaccard, S.L., Galbraith, E.D., Froelicher, T.L., Gruber, N., 2014. Ocean

465 (De)Oxygenation across the last deglaciation, insights for the future. Oceanography $27,26-35$.

Jaccard, S.L., Galbraith, E.D., Martínez-Garcia, A., Anderson, R.F., 2016. Covariation of deep Southern Ocean oxygenation and atmospheric CO2 through the last ice age. Nature .

Keeling, R.F., Körtzinger, A., Gruber, N., 2010. Ocean deoxygenation in a warming world. Annual Review of Marine Science 2, 199-229.

Lu, Z., Hoogakker, B.A.A., Hillenbrand, C.D., Zhou, X., Thomas, E., Gutchess, K.M., Lu, W., Jones, L., Rickaby, R.E.M., 2016. Oxygen depletion recorded in upper waters of the glacial Southern Ocean. Nature Communications 7, 11146. 
Matear, R., Hirst, A., McNeil, B., 2000. Changes in dissolved oxygen in the Southern Ocean with climate change. Geochemistry, Geophysics, Geosystems 1, 1050.

McManus, J., Berelson, W.M., Klinkhammer, G.P., Hammond, D.E., Holm, C., 2005. Authigenic uranium: relationship to oxygen penetration depth and organic carbon rain. Geochimica et Cosmochimica Acta 69, 95-108.

${ }_{480}$ McManus, J., Berelson, W.M., Severmann, S., Poulson, R.L., Hammond, D.E., Klinkhammer, G.P., Holm, C., 2006. Molybdenum and uranium geochemistry in continental margin sediments: Paleoproxy potential. Geochimica et Cosmochimica Acta 70, 4643-4662.

Morford, J.L., Emerson, S., 1999. The geochemistry of redox sensitive trace metals in 485 sediments. Geochimica et Cosmochimica Acta 63, 1735-1750.

Muratli, J., Chase, Z., Mix, A., McManus, J., 2009. Increased glacial-age ventilation of the Chilean margin by Antarctic Intermediate Water. Nature Geoscience 3, 23-26.

Murphy, R.J., Pinkerton, M.H., Richardson, K.M., Bradford Grieve, J.M., Boyd, P.W., 2001. Phytoplankton distributions around New Zealand derived from SeaWiFS remotely-sensed ocean colour data. New Zealand Journal of Marine and Freshwater Research 35, 343-362.

Nevison, C.D., Weiss, R.F., Erickson, D.J., 1995. Global oceanic emissions of nitrous oxide. Journal of Geophysical Research 100, 15809-15820.

Pahnke, K., Zahn, R., 2005. Southern Hemisphere water mass conversion linked with North Atlantic climate variability. Science 307, 1741-1746.

Paillard, D., Labeyrie, L., Yiou, P., 1996. Macintosh program performs time-series analysis. Eos, Transactions American Geophysical Union 77, 379-379.

Peterson, C.D., Lisiecki, L.E., Stern, J.V., 2014. Deglacial whole-ocean $\delta 13 C$ change estimated from 480 benthic foraminiferal records. Paleoceanography 29, 549-563. 
Piola, A.R., Georgi, D.T., 1982. Circumpolar properties of Antarctic intermediate water and Subantarctic Mode Water. Deep Sea Research Part A. Oceanographic Research Papers 29, 687-711.

Ramsey, C.B., 2009. Bayesian analysis of radiocarbon dates. Radiocarbon 51, 337-360.

Rintoul, S.R., Bullister, J.L., 1999. A late winter hydrographic section from Tasmania to Antarctica. Deep Sea Research Part I: Oceanographic Research Papers 46, 14171454.

Ronge, T.A., Steph, S., Tiedemann, R., Prange, M., Merkel, U., Nürnberg, D., Kuhn, G., 2015. Pushing the boundaries: Glacial/Interglacial variability of intermediate- and deep-waters in the southwest Pacific over the last 350,000 years. Paleoceanography 30, 23-38.

Rousseau, J., Ellwood, M.J., Bostock, H.C., Neil, H., 2016. Estimates of late Quaternary mode and intermediate water silicic acid concentration in the Pacific Southern Ocean. Earth and Planetary Science Letters 439, 101-108.

Rudnick, R.L., Gao, S., 2003. Composition of the Continental Crust. Treatise on Geochemistry 3, 1-64.

Sabine, C.L., Feely, R.A., Gruber, N., Key, R.M., Lee, K., Bullister, J.L., Wanninkhof, R., Wong, C.S., Wallace, D.W.R., Tilbrook, B., Millero, F.J., Peng, T.H., Kozyr, A., Ono, T., Rios, A.F., 2004. The oceanic sink for anthropogenic CO2. Science 305, 367-371.

${ }_{520}$ Sallee, J.B., Speer, K., Rintoul, S., Wijffels, S., 2010. Southern Ocean Thermocline Ventilation. Journal of Physical Oceanography 40, 509-529.

Schlitzer, R., 2017. Ocean Data View. http://odv.awi.de/ .

Schmidtko, S., Stramma, L., Visbeck, M., 2017. Decline in global oceanic oxygen content during the past five decades. Nature 542, 335-339.

${ }_{525}$ Schmittner, A., Bostock, H.C., Cartapanis, O., Curry, W.B., Filipsson, H.L., Galbraith, E.D., Gottschalk, J., Herguera, J.C., Hoogakker, B., Jaccard, S.L., Lisiecki, L.E., 
Lund, D.C., Martínez-Méndez, G., Lynch Stieglitz, J., Mackensen, A., Michel, E., Mix, A.C., Oppo, D.W., Peterson, C.D., Repschläger, J., Sikes, E.L., Spero, H.J., Waelbroeck, C., 2017. Calibration of the carbon isotope composition $(\delta 13 \mathrm{C})$ of benthic foraminifera. Paleoceanography, n/a-n/a.

Schmittner, A., Gruber, N., Mix, A.C., Key, R.M., Tagliabue, A., Westberry, T.K., 2013. Biology and air-sea gas exchange controls on the distribution of carbon isotope ratios $\left(\delta^{13} C\right)$ in the ocean. Biogeosciences 10, 5793-5816.

Skinner, L., McCave, I.N., Carter, L., Fallon, S., Scrivner, A.E., Primeau, F., 2015. Reduced ventilation and enhanced magnitude of the deep Pacific carbon pool during the last glacial period. Earth and Planetary Science Letters 411, 45-52.

Skinner, L.C., Primeau, F., Freeman, E., de la Fuente, M., Goodwin, P.A., Gottschalk, J., Huang, E., McCave, I.N., Noble, T.L., Scrivner, A.E., 2017. Radiocarbon constraints on the glacial ocean circulation and its impact on atmospheric $\mathrm{CO} 2$. Nature Communications 8, 16010.

Sloyan, B.M., Rintoul, S.R., 2001. Circulation, Renewal, and Modification of Antarctic Mode and Intermediate Water. Journal of Physical Oceanography 31, 1005-1030.

Talley, L.D., 2013. Closure of the Global Overturning Circulation Through the Indian, Pacific, and Southern Oceans: Schematics and Transports. Oceanography 26, 80-97.

Tribovillard, N., Algeo, T.J., Lyons, T., Riboulleau, A., 2006. Trace metals as paleoredox and paleoproductivity proxies: An update. Chemical Geology 232, 12-32.

Voigt, I., Chiessi, C.M., Prange, M., Mulitza, S., Groeneveld, J., Varma, V., Henrich, R., 2015. Holocene shifts of the Southern Westerlies across the South Atlantic. Paleoceanography .

Wagner, M., Hendy, I.L., 2017. Trace metal evidence for a poorly ventilated glacial Southern Ocean. Quaternary Science Reviews 170, 109-120.

Zheng, Y., Anderson, R.F., van Geen, A., Fleisher, M.Q., 2002a. Preservation of particulate non-lithogenic uranium in marine sediments. Geochimica et Cosmochimica Acta 66, 3085-3092. 
Zheng, Y., Anderson, R.F., van Geen, A., Fleisher, M.Q., 2002b. Remobilization of authigenic uranium in marine sediments by bioturbation. Geochimica et Cosmochimica Acta 66, 1759-1772.

\section{Supplementary figures}

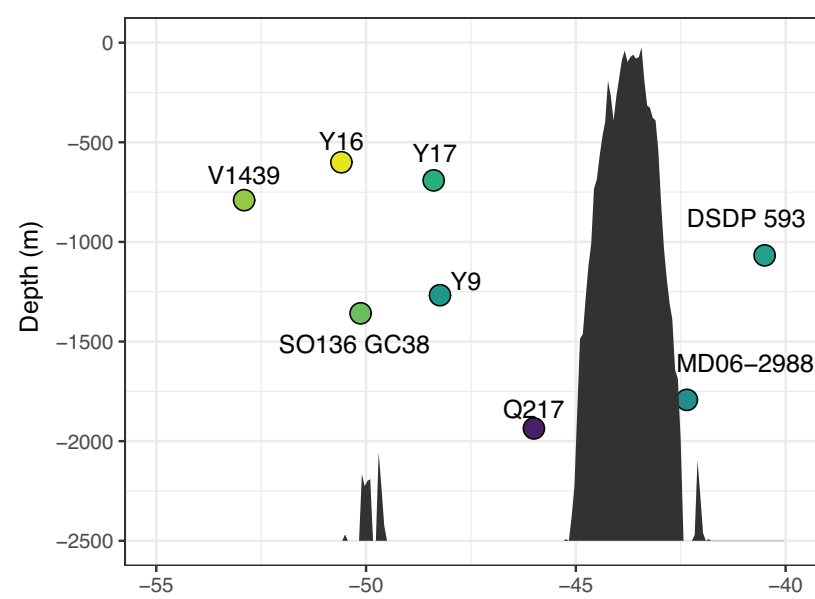

aU LGM-Holocene change $(\mathrm{mg} / \mathrm{kg})$

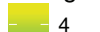

$-2$

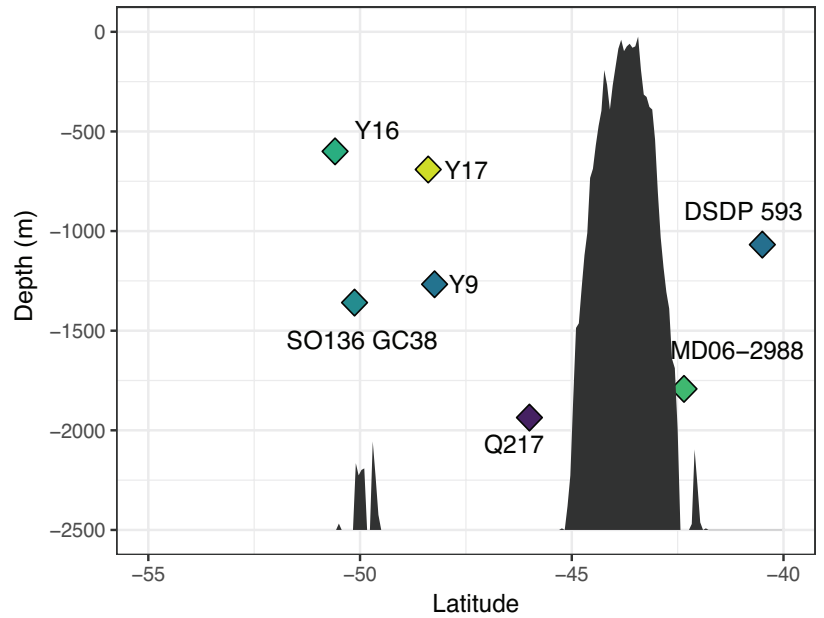

aRe LGM-Holocene change $(\mu \mathrm{g} / \mathrm{kg})$ 20

Figure S1: Differences in authigenic U and Re between the LGM (18-25 ka) and the Holocene (5-12 ka) as a function of depth and latitude. Bathymetric transect at $182^{\circ}$ was plotted. 

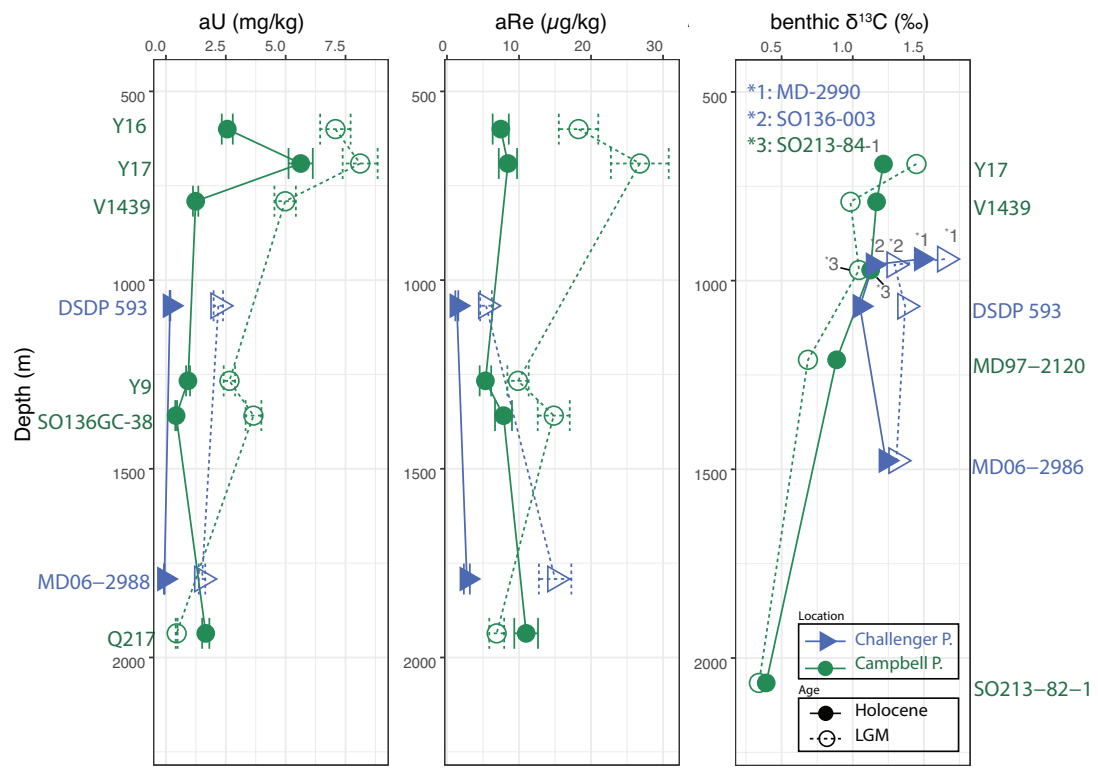

Figure S2: Same as Figure 4 except the glacial $\delta^{13} C$ values were corrected for the global isotopic shift by adding $0.34 \%$ (Peterson et al. 2014). 